3. Концепція нової української школи [Електронний ресурс] Режим доступу : https://mon.gov.ua/storage/app/media/zagalna\%20 serednya/nova-ukrainska-shkola-compressed.pdf

DOI https://doi.org/10.30525/978-9934-588-90-7-6

\title{
СИЛЬНА ТА СЛАБКА СЛОВОТВІРНА НОРМА В ХУДОЖНІЙ ПРОЗІ
}

\author{
Засць В. Г. \\ кандидат педагогічних наук, \\ доиент кафедри украӥнської мови \\ Київький університет імені Бориса Грінченка \\ м. Київ, Украӥна
}

Аналізовані художні твори новітньої доби експліцитно демонструють 3 одного боку, тенденції відродження словотвірної норми, іiі відповідність чинним мовним нормам, сталість та константність літературних взірців, а з іншого - певну нестабільність, рухливість, подекуди мінливість.

В україністиці мовна практика сучасної художньої прози розглядається здебільшого у площині особливостей словотворчості окремого автора або авторів, що контекстуально втілює уміння письменника лексичними засобами передавати співіснування мови на тлі концептуальної картини світу.

Авторський текст художнього стилю незалежно від жанрової специфіки відбиває продуктивні, малопродуктивні словотвірні типи та співіснування в узусі прескриптивної та дескриптивної норм, що стали об'єктом досліджень К. Городенської, С. Єрмоленко, С. Бибик, О. Стишова, Л. Кислюк, Т. Коць та ін. [1;7].

Українська літературна мова художнього стилю в останні три десятиріччя утверджувала престиж надбання нації, об'єднувала носіїв навколо словотворчості письменників, ілюструвала особливості авторського ідіостилю.

Зокрема помічено, що в іменниковому словотворенні художньої прози новітньої доби активністю позначений словотвірний тип на позначення осіб «за місцем народження, проживання» похідними дериватами чоловічого роду з найуживанішими суфіксами -анин (-янин), -чанин, -ин, -ак (-як), на зразок: австріяк, батуринець, галичанин, 
львів'янин, житомирянин, надніпрянещь та ін. Пор.: Тут несподівано я перечепилася в порозі й мене підхопив під руку, не давши впасти, уже знайомий житомирянин [9, с. 136]. Проте зауважимо, що об'єктивний аналіз мовної дійсності дає підстави відзначати конкуренцію словотвірного типу іменників з суфіксом -янин та -ець. В узусі відомі кодифіковані варіанти назв мешканців міста, що виступають твірними для утворення варіантів похідних, на зразок: житомирянин та житомирець [10, с. 666]. Таку конкуренцію афіксальних морфем фіксує «Тлумачний словник української мови», на зразок: береговець берегівчанин, бережанець - бережанин, бродівець - бродівчанин, вільшанин - вільшановець, глуховець - глухівчанин, долинеиь - долинянин, гребінковець - гребінчанин, долинець - долинянин, жмеринеиь жмеринчанин, ічнянин - чернігівець - чернігівчанин, ічнянець, ізмайлець ізмаӥльчанин, канівець - канівець, холминець - холмичанин, чернігівець чернігівчанин, чугуївець - чугуївчанин, шполянець - шполянин, юр'ївець юр 'їчанин [10, с. 665-670].

У такий спосіб важко визначити сильну норму для маркування осіб, приналежних до місця народження, проживання. Свого часу I. Ковалик зауважував про складність у визначенні ступеня продуктивності як окремих афіксів, так і окремих словотвірних типів [6, с. 226]. Вчений вважав, що «об'єктивно в мовній дійсності виявляються різні ступені продуктивності тих чи інших словотвірних типів чи самих афіксів, їх можна поділити на живі - продуктивні, малопродуктивні, непродуктивні, вимираючі і мертві» [6, с. 226].

На наше глибоке переконання, час продемонструє норму сильну, яка буде мовцями вибрана, водночас слабка - відійде на периферію як така, що відкинута узусом.

Помічено, що словотвірний тип іменників на позначення осіб «за територіальними ознаками» зберіг свою продуктивність у художній прозі історичної тематики. Стійкість словотвірної норми досягається завдяки суфіксу -ець, що надає чіткості в передаванні історичних подій, відомих персоналій, на зразок: горбулівець, наддніпрянець.

Проте сталість вживання афікса -ець демострують тексти художньої прози, на зразок: горбулівець, наддніпрянещьь. Пор.: Горбулівці пояснять Санькові, щяо він прикінчив самого Аралова, бо знайдуть у вбитого срібний портсигар, на якому вигравіювані ведмедики в ранковому лісі, $i$ віддадуть той портсигар Санькові як його законну трофейну здобич [11, с. 43]; Осипу по ией бік Збруча вже не раз доводилося чути, що він гуиул, - че звичайно, ближче, ніж австріяка, але теж пальцем в небо [11, с. 117]; Стара діва з розмазаною на лиџі крейдою штурхала 
гострими кулаками засмаглого козака під ребра, щуипала його, називала «чьортов гуцул», не відрізняючи наддніпрянця від галичанина [11, c. 129].

Вищеназваний словотвірний тип зберігає продуктивність у сучасній художній прозі, що представлена соціально-психологічним романним жанром, на зразок: шанівці. Пор.: За фермою - глиняна мазанка глухої бабки Килини, $i$ другу дорогу ще видко серед буряків - не тому, щчо шанівці полюбляють ходити до розтрощеної будівлі та згадувати добрі часи <...>; Ніхто із шанівців не розуміє, хто й навішо проклав свого часу изю колію до кургану, щзо височіє біля села [2, с. 10].

Сильну словотвірну норму фіксують назви осіб у пригодницькому романі Макса Кідрука [4], що мешкають в інших країнах, на зразок: єзиптянин, кубанець, македонянин, новозеландецьь, сирієць, флорентієць. Пор.: Посеред тижня в «Саiro Stars» лишилося тільки троє постояльців: флорентієць Марко, його дружина Мійя $і$ я [4, с. 94]; Новозеландець виграв у конкурсі дружину з Украӥни [4, с. 34].

Зауважимо, що в романному жанрі письменника Макса Кідрука не помічаємо взаємозаміщення словотвірних афіксів, а отже, здатності до конкуренції між словотвірними типами, на зразок: македонієць i македонянин.

Пор. : Стерши на попіл перські війська під Іссом, великий македонянин узимку 332-331 рр. до н.е. прийшов у Сгипет [4, с. 30]; Нубійські племена водили Камбіса за носа, уникаючи прямих сутичок $і$ помалу вимотуючи ворога. Нубійці досягли свого [4, с. 32]; Новозеландець виграв у конкурсі дружсну з Украӥни [4, с. 32].

Отже, українська літературна мовна норма творів новітньої доби демонструє слабкі та сильні словотвірні типи для маркування осіб за приналежністю до певного місця народження, проживання. Продуктивність одного словотвірного типу пов'язана 3 частотністю вживання в узусі, зі здатністю до взаємозаміщення та конкуренції.

\section{Література:}

1. Городенська К.Г. Українське слово у вимірах сьогодення : монографія. Київ : КММ. 2014. 124 с.

2. Дашвар Люко. Село не люди : роман. Харків : Харків : Книжковий клуб: Клуб Сімейного дозвілля, 2016. 270с.

3. Карпіловська С. А. Норма в сучасному українському словотворенні: зразок і реальність. Культура слова. 2011. № 74. С. 43-51.

4. Кідрук М. На Зеландію : роман. Харків : Книжковий Клуб «Клуб Сімейного Дозвілля». 2014. 256 с. 
5. Кислюк Л. П. Словотвірна номінація в сучасній українській мові: система - узус - ідіолект : дис. ... д-ра. філол. наук : 10.02.01. Київ, 2018. 616 c. URL : http://shron1.chtyvo.org.ua/Kysliuk_Larysa/Slovotvirna_ nominatsiia_v_suchasnii_ukrainskii_movi_systema_uzus_idiolekt.pdf (дата звернення: 02.07.2020).

6. Ковалик I. І. Вчення про словотвір : вибрані праці. / Упорядник та автор передмови Василь Грещук. - Івано-Франківськ-Львів: Місто НВ, 2007. -404 c.

7. Літературна норма i мовна практика : монографія / С. Я. Єрмоленко та ін. ; за ред. С. Я. Єрмоленко. Київ, 2013. 320 с.

8. Нариси з основоцентричної дериватології / В. В. Грещук та ін. ; за ред. В. В. Грещука. Івано-Франківськ : Місто НВ, 2007. 348с.

9. Смола О. Віват, життя! Літературна Украӥна. 2017. 02 лютого. C. $8-9$.

10. Тлумачний словник української мови / уклад. Т. В. Ковальова, Л. П. Коврига. Харків : Синтекс, 2002. 672 с.

11. Шкляр В. М. Маруся : роман. Харків : Книжковий Клуб «Клуб Сімейного Дозвілля». 2014. 384 с.

DOI https://doi.org/10.30525/978-9934-588-90-7-7

\title{
ВТРУЧАННЯ РАДЯНСЬКОЇ ВЛАДИ У ВНУТРІШНЮ БУДОВУ УКРАЇНСЬКОЇ МОВИ (НА ПРИКЛАДІ СКЛАДНИХ ПРИКМЕТНИКІВ)
}

\author{
Коца Р. О. \\ кандидат філологічних наук,
} науковий співробітник відділу історії украӥнської мови та ономастики Інститут украӥнської мови Національної академії наук України м. Київ, Україна

На початку 30-х pp. XX ст. політика українізації остаточно припиняється, хоча формально вона ніколи не була скасована. Для цієї справи Й. Сталін направляє в Україну П.П. Постишева, основним гаслом культурної політики якого було усунення штучних бар'єрів між українською та російською націями і культурами. Починається боротьба проти «націоналізму» й «шкідництва» в мовознавстві. 